\title{
PEMBERDAYAAN KELOMPOK DASAWISMA DALAM PEMANFAATAN TANAMAN OBAT KELUARGA (TOGA) DI KELURAHAN KENALI ASAM BAWAH
}

\author{
Nurfitriani $^{1)}$, Tina Yuli Fatmawati ${ }^{2)}$ \\ ${ }^{1,2}$ Prodi' D III Keperawatan, STIKes Baiturrahim Jambi \\ email: nurfitriani_1173@yahoo.com
}

\begin{abstract}
One program that can be implemented by the community in an effort to improve family welfare, especially in the field of food is the planting and utilization program of Family Medicinal Plants (TOGA). TOGA is a home-grown plant that has medicinal properties. TOGA planting can be done in pots or on land around the house. The Kelurahan Kenali Asam Bawah is one of the Kelurahan in Kota Baru Subdistrict where the community in the region generally still has a large enough yard, so that the utilization and management of the environment can be optimized by planting TOGA. Based on field observations, the Dasawiwma group did not have a pilot family of medicinal plants. Some of them also do not understand the efficacy of TOGA scientifically. Therefore it is necessary to conduct socialization / counseling about the efficacy of TOGA so that people can have knowledge about the efficacy of TOGA. The target of this community service activity is the dasawisma group d RT 047 The target target is 10 people in one dasawima group especially in Kelurahan Kenali Asam Bawah. The aim of community service is expected after participating in the socialization of Dasawisma The group leader is able to understand and be willing to motivate his group members about the importance of planting TOGA. The results obtained with the procurement of plants and the socialization of the use of the TOGA $100 \%$ increased knowledge of the participants.
\end{abstract}

Keywords: dasawisma, family Efficacy, medicinal Plants

\begin{abstract}
ABSTRAK
Salah satu program yang dapat dilaksanakan oleh masyarakat dalam upaya peningkatan kesejahteraan keluarga, khususnya di bidang pangan adalah program penanaman dan pemanfaatan Tanaman Obat Keluarga (TOGA). TOGA adalah tanaman hasil budidaya rumahan yang berkhasiat sebagai obat. Penanaman TOGA dapat dilakukan di pot atau di lahan sekitar rumah. Kelurahan Kenali Asam Bawah merupakan salah satu Kelurahan di Kecamatan Kota Baru yang umumnya masyarakat di wilayah tersebut masih memiliki lahan pekarangan yang cukup luas, sehingga pemanfaatan dan pengelolaan lingkungan dapat dioptimalkan dengan penanaman TOGA. Berdasarkan observasi di lapangan diperoleh Kelompok dasawiwma tidak memiliki tanaman obat keluarga percontohan . Sebagian dari mereka juga belum memahami khasiat TOGA secara ilmiah. Oleh karena itu perlu dilakukan sosialisasi/penyuluhan tentang khasiat TOGA sehingga masyarakat dapat memiliki pengetahuan tentang khasiat TOGA. Sasaran kegiatan pengabdian ini adalah kelompok dasawisma d RT 047 Target sasaran berjumlah 10 orang dalam satu kelompok dasawima khusunya di Kelurahan Kenali Asam Bawah. Tujuan dari pengabdian masyarakat ini diharapkan setelah mengikuti sosialisasi Dasawisma Ketua kelompok mampu memahami dan mau memberikan motivasi kepada anggota kelompoknya tentang pentingnya penanaman TOGA. Hasil yang diperoleh dengan adanya pengadaan tanaman dan sosialisasi pemanfaatan TOGA ini $100 \%$ terjadi peningkatan pengetahuan dari peserta.
\end{abstract}

Kata Kunci : dasawisma, pemberdayaan keluarga, tanaman obat 


\section{PENDAHULUAN}

Kemajuan di berbagai bidang akibat majunya ilmu pengetahuan dan teknologi merupakan tantangan besar bagi perempuan untuk senantiasa mampu memanfaatkan dan mengelola lingkungannya. Oleh karena itu diperlukan adanya berbagai program yang dapat dilakukan perempuan dalam rangka peningkatan kesejahteraan keluarga dengan memanfaatkan dan mengelola lingkungan sekitarnya. Lahan pekarangan yang dikelola secara optimal dapat memberikan manfaat bagi rumah tangga dan keluarga. Hal ini dapat dilihat dari beragam fungsi dasar pekarangan yaitu menjadi warung hidup, bank hidup dan apotik hidup serta fungsi keindahan. Lahan pekarangan yang dikelola dengan baik dapat memberikan manfaat antara lain adanya peningkatan gizi keluarga, tambahan pendapatan keluarga, lingkungan rumah menjadi asri, teratur , indah dan nyaman.

Salah satu program yang dapat dilaksanakan oleh masyarakat dalam upaya peningkatan kesejahteraan keluarga, khususnya di bidang pangan adalah program penanaman dan pemanfaatan Tanaman Obat Keluarga (TOGA). TOGA adalah tanaman hasil budidaya rumahan yang berkhasiat sebagai obat. Penanaman TOGA dapat dilakukan di pot atau di lahan sekitar rumah, Bila lahan yang ditanami cukup luas maka sebagian hasil panen dapat dijual dan menambah pendapatan keluarga. Adapun pemanfaatan TOGA selain sebagai obat, juga dapat dimanfaatkan untuk: (1) penambah gizi keluarga (pepaya, timun, bayam), (2) bumbu atau rempah-rempah masakan (kunyit, kencur, jahe, serai, daun salam), (3) menambah keindahan (mawar, melati, bunga matahari, kembang sepatu, tapak dara, kumis kucing).

Kelurahan Kenali Asam Bawah merupakan salah satu Kelurahan di Kecamatan Kota Baru yang umumnya masyarakat di wilayah tersebut masih memiliki lahan pekarangan yang cukup luas, sehingga pemanfaatan dan pengelolaan lingkungan dapat dioptimalkan dengan penanaman TOGA. Berdasarkan observasi di lapangan diperoleh Kelompok dasawiwma tidak memiliki tanaman obat keluarga percontohan. Sebagian dari mereka juga belum memahami khasiat TOGA secara ilmiah. Oleh karena itu perlu dilakukan sosialisasi/penyuluhan tentang khasiat TOGA secara ilmiah. Sehingga masyarakat dapat memiliki pengetahuan tentang khasiat TOGA dan menguasai cara pengolahannya dan memanfaatkannya sehingga akan terwujud prinsip kemandirian dalam pengobatan keluarga. Selain itu juga dapat dikembangkan menjadi usaha kecil dan menengah di bidang obat-obatan herbal, yang selanjutnya dapat disalurkan ke masyarakat. Oleh Tim Pengabdi mencoba untuk melakukan pengabdian kepada masyarakat dengan mengambil judul " Pemberdayaan Kelompok Dasawisma Dalam Pemanfaatan Tanaman Obat Keluarga (Toga) Di Kelurahan Kenali Asam Bawah

\section{TARGET DAN LUARAN}

\begin{tabular}{|c|c|c|}
\hline No & Kegiatan & Target (\%) \\
\hline 1 & $\begin{array}{l}\text { Sosialisasi kepada } \\
\text { kader dasawisma } \\
\text { tentang } \\
\text { pentingnya TOGA }\end{array}$ & $\begin{array}{l}90 \% \text { Ketua dan } \\
\text { anggota } \\
\text { dasawisma } \\
\text { memahami } \\
\text { pentingnya } \\
\text { TOGA }\end{array}$ \\
\hline 2 & Pengadaan & Tersedianya \\
\hline & TOGA & $\begin{array}{l}\text { TOGA seperti } \\
\text { jahe, kunyit, } \\
\text { jeruk nipis dan } \\
\text { lain-lain }\end{array}$ \\
\hline 3 & $\begin{array}{l}\text { Penanaman } \\
\text { TOGA di Lahan } \\
\text { Kelompok } \\
\text { Dasawisma }\end{array}$ & $\begin{array}{l}\text { Telah dilakukan } \\
\text { dengan } \\
\text { menambah } \\
\text { tanaman TOGA }\end{array}$ \\
\hline
\end{tabular}




\section{B. LUARAN}

Selain Publikasi ilmiah pada Jurnal Nasional ber ISSN, luaran penelitian ini juga diharapkan dapat terjadi peningkatan pengetahuan, penerapan IPTEK dimasyarakat

\section{METODE PELAKSANAAN}

Sasaran kegiatan pengabdian ini adalah ibu-ibu kelompok dasawisma d RT 047 Target sasaran berjumlah 10 orang dalam satu kelompok dasawima khusunya di Kelurahan Kenali Asam Bawah. Tujuan dari pengabdian masyarakat ini diharapkan setelah mengikuti sosialisasi Dasawisma Ketua kelompok mampu memahami dan mau memberikan motivasi kepada anggota kelompoknya tentang pentingnya penanaman TOGA. Adapun Metode pelaksanaan pengabdian kepada masyarakat telah dilakukan sesuai dengan rencana dapat diuraikan sebagai berikut :

1. Pertemuan dengan Ketua Dasawisma tentang rencana pengabdian masyarakat

2. Pada tahap Implementasi: pengadaan TOGA dan penanaman TOGA

3. Pemberian Leaflet tentang khasiat tanaman obat

4. Metode selanjutnya adalah mengajak peserta untuk menanam toga di halaman rumahnya dengan menggunakan pot (untuk jenis tanaman yang dapat ditanam dalam pot).

5. Diskusi dan tanya jawab mengenai permasalahan yang berkaitan dengan pemanfaatan tanaman obat untuk mengobati penyakit di masyarakat.

6. Monitoring dan evaluasi

\section{HASIL DAN PEMBAHASAN}

\section{Hasil}

Pelaksanaan kegiatan pengabdian ini telah dilaksanakan pada bulan Bulan Februari 2019 semua terlaksana sesuai dengan rencana yang telah disusun.
Kegiatan ini dibantu oleh 2 mahasiswa program studi D3 Keperawatan. Dengan adanya pengadaan tanaman dan pemanfaatan TOGA ini $100 \%$ terjadi peningkatan pengetahuan dari peserta tentang khasiat aneka jenis tanaman obat dan tata cara penanamannya yang baik, serta keterampilan mengolah tanaman TOGA. Peserta juga dapat mengelola, mengatur dan memanfaatkan pekarangan disekitar rumah, serta optimalisasi lahan pekarangan sehingga dapat meningkatkan kesejahteraan keluarga.

Menurut Kemenkes RI 2011, Secara garis besar, TOGA banyak memberikan manfaat dari segi kesehatan, lingkungan, ekonomi dan sosial budaya yaitu:

\section{Aspek Kesehatan}

a) Pemeliharaan Kesehatan

TOGA yang berperan sebagai obat tradisional banyak digunakan sebagai upaya pencegahan. (Upaya preventif).

b) Penanggulangan Penyakit

Banyak TOGA yang sangat bermanfaat menurunkan morbiditas dan mortalitas dari suatu penyakit seperti hipertensi dan diabetes.

c) Perbaikan Status Gizi

Ada TOGA yang dikenal sebagai tanaman buah-buahan dan sayuran seperti papaya, pisang dan daun katuk namun dapat digunakan sebagai obat.

\section{Aspek Lingkungan}

a) Kelestarian alam

Saat ini banyak simplisia nabati yang berasal dari tumbuhan liar yang mana nantinya jika tidak dibudidayakan maka tumbuhan tersebut akan punah dan kepunahan tersebut akan punah.

b) Penghijauan dan Estetika

Dengan menggalakkan penanaman tanaman obat, berarti juga menggalakkan penghijauan. Tanaman obat yang tinggi dan tertata baik dapat memberikan keindahan pada lingkungan. Tanaman yang 


\section{Aspek Ekonomi}

Peningkatan pendapatan masyarakat desa.Tanaman obat dapat meningkatkan pendapatan masyarakat desa karena dengan menanam tanaman obat tersebut masyarakat dapat menggunakan tanaman tersebut sebagai obat namun tanaman obat tersebut dapat dijual sehingga menambah penghasilan, selain itu tanaman obat tersebut dapat diolah terlebih dahalu seperti menjadi minuman sachet sehingga menambah nilai jual.

\section{Aspek Sosial Budaya}

Dengan penanaman TOGA merupakan upaya pelestarian budaya leluhur dalam memelihara dan mempertahankan budaya masyarakat

Keberhasilan

pelaksanaan pengabdian kepada masyarakat ini dapat dilihat dari ketercapaian target yaitu adanya keterlibatan dan kehadiran kelompok Dasawisma yang antusias dalam menerima tim pengabdi. Evaluasi dari program kegiatan pengabdian kepada masyarakat dilaksanakan dimulai dari perencanaan, pelaksanaan dan evaluasi hasil.

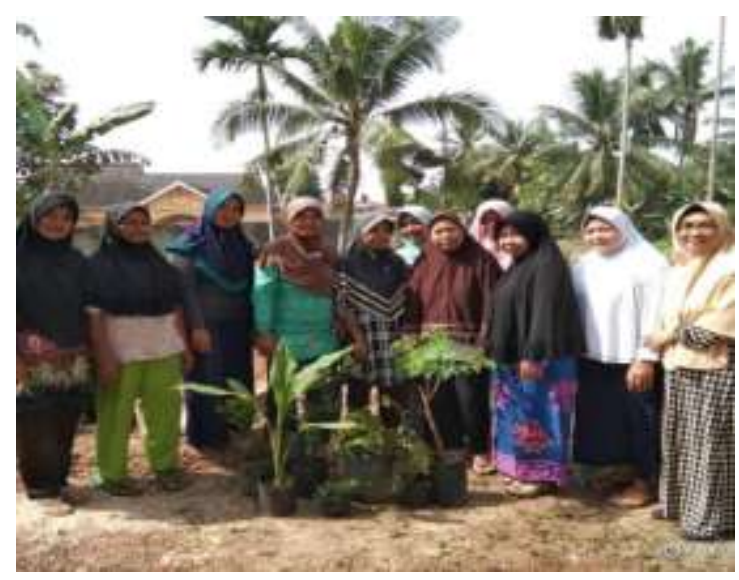

\section{Luaran yang dicapai}

Luaran dari kegiatan pengabdian ini yaitu:

a. Publikasi artikel pada jurnal pengabdian masyarakat (draf)

b. Tersedianya Media KIE ( poster /leflet)

c. Terlaksananya Pengadaan TOGA

d. Terjadi peningkatan pengetahuan peserta tentang manfaat TOGA.
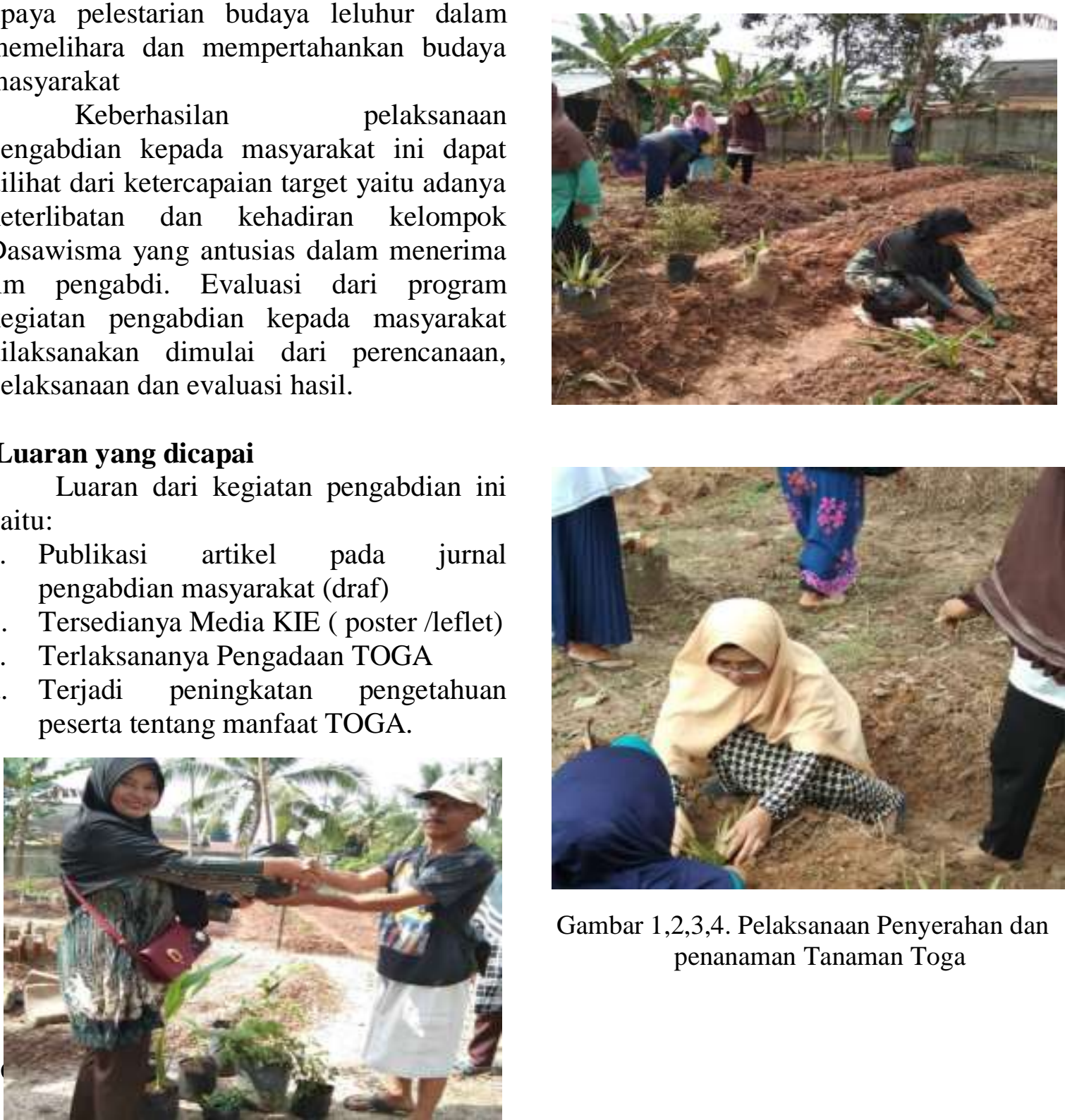

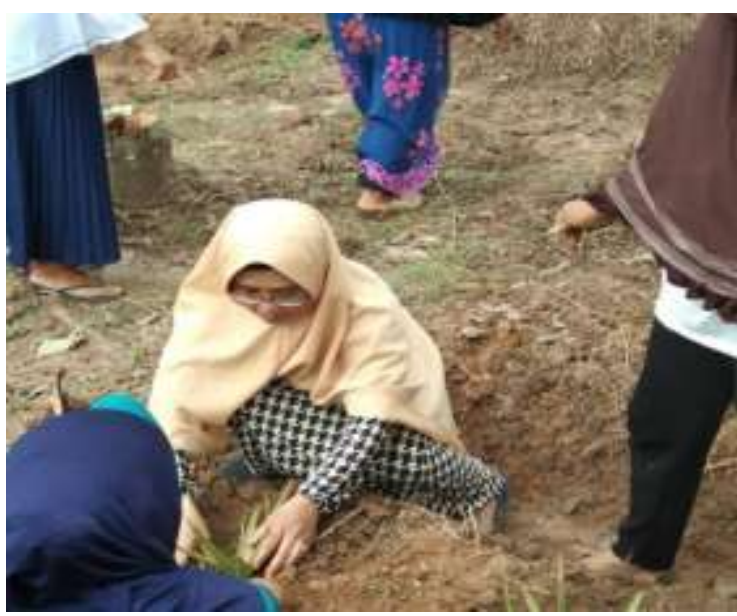

Gambar 1,2,3,4. Pelaksanaan Penyerahan dan penanaman Tanaman Toga 


\section{KESIMPULAN DAN SARAN}

\section{A. KESIMPULAN}

Kegiatan pengabdian masyarakat dengan tema sosialisasi Pemanfaatan Tanaman Obat untuk Kesehatan telah dilaksanakan pada minggu kedua s/d ke empat. Kegiatan ini berjalan lancar dan mendapat perhatian positif dari masyarakat. Masyarakat sangat mengharapkan adanya program lain yang mendukung keberlangsungan program ini, diantaranya adalah cara penanaman tanaman yang baik, serta masyarakat menginginkan adanya praktek pembuatan ekstrak dari tanaman obat. Adanya sosisalisasi ini juga dapat meningkatkan pengetahuan kelompok dasawisma tentang aneka jenis tanaman obat dan khasiatnya, meningkatkan keterampilan pengolahan tanaman obat menjadi bahan minuman.

\subsection{Saran}

Kepada kelompok Dasawisma dapat menyebarluaskan manfaat TOGA ke kelompok lainnya dan menambah beberapa jenis tanaman sehingga dapat menambah berbagai macam jenis TOGA di kelompoknya. Bagi warga yang tidak mempunyai halaman yang cukup luas bisa menggunakan rak-rak dan pot-pot paralon.

\section{UCAPAN TERIMAKASIH}

Termakasih kepada Sekolah Tinggi Ilmu Kesehatan Baiturrahim, Bapak Lurah Kenali Asam Bawah, Ketua RT 47 dan Ibu Ketua PKK Kenali asam Bawah Jambi yang telah menduung dan memfasilitasi kegiatan pengabdian kepada masyarakat ini, sehingga kegiatan ini dapat terwujud.

\section{DAFTAR PUSTAKA}

Ahmad, 2009. Tingkat Pengetahuan, Sikap dan Azizah, Lilik Ma'rifatul. (2011). Keperawatan Lanjut Usia, Ed.1. Graha Ilmu. Yogyakarta.
Depkes RI, 2010, Pedoman Umum Pengembangan Desa dan Kelurahan Siaga Aktif. Jakarta : Pusat Promosi Kesehatan Sekretaris Jenderal Kementerian Kesehatan RI

Darmojo,B.R, dan Martono.H. 2004. Buku Ajar Geriatri. Balai Penerbit FKUI. Jakarta.

Kementerian Kesehatan RI. 100 Top Tanaman Obat Indonesia. Jakarta: Badan Penelitian dan Pengembangan Kesehatan Balai Besar Penelitian dan Pengembangan Tanaman Obat dan Obat Tradisional; 2011

Nugroho, Wahjudi. (2014). Keperawatan Gerontik \& Geriatrik, Ed.3. EGC. Jakarta

Padila. 2013. Buku Ajar Keperawatan Gerontik. Numed. Yogyakarta.

Praktek Keluarga Tentang Pencegahan DBD. Jakarta : Skripsi. Perpus. Fkik.uinjkt.ac.id./file_digital /Ahmad.pdf. 30-08-2012 jam 10:06 wib.

Anton, 2008. Hubungan Perilaku Tentang Pemberantasan Sarang Nyamuk dan Kebiasaan keluarga dengan Kejadian Demam Berdarah Dengue. Medan: Skripsi. Eprints.undip.ac.id/16497/1/Anton.pdf. 31-12-2011 jam 09:34 wib. 